\title{
THE 1832 CHOLERA EPIDEMIC IN YORK
}

by

\author{
MARGARET C. BARNET
}

RECURRENT EPIDEMICS of cholera spread across Asia and Eastern Europe during the second decade of the nineteenth century and it seemed that it would continue to travel westwards until it reached this country. The newspapers contained many references to this possibility, the government discussed methods of dealing with the expected outbreak; in medical journals and newly-published books medical men considered its nature and the best means of treatment.

In the autumn of 1831 the committee of the York Dispensary met to consider how medical aid could best be provided if there was an outbreak of cholera in the city. The newly-founded York Medical Society held its first meeting in February 1832 and its first nine lectures were devoted exclusively to this subject.

By the spring of 1832 cholera was already occurring in Hull, Selby and Leeds, so York observed the warning and made preparations. In April, on instructions from the Privy Council, the Lord Mayor convened the reconstituted Board of Health which was now to be composed exclusively of clergymen, magistrates, gentlemen and medical men. One of its first decisions was to reject the idea of using the city moats and ramparts as burial grounds. If this suggests an unusual sense of priorities, then the acrimonious arguments which continued for such a long time make it apparent that this was a very sensitive subject. More practical measures were then recommended. Funds were to be provided to supply food, clothing and blankets. Parochial Officers were instructed to visit houses to ensure that all sources of filth were removed; rooms of those who could not do it themselves, were to be cleaned and whitewashed, as were pigstyes, privies and soil-holes. The medical men reported weekly to the Board on the state of health of the community, saying that never in the whole of their professional experience had so little disease prevailed in York. 'No one dreamed that we were just on the eve of an eruption of cholera, because as far as human means are available everything has been removed that is considered likely or even possible to generate the disease. . . . It will be met by so much cleanliness, comfort and temperance that it can hardly obtain an extensive prevalence among us.'

Reassured by these preparations the citizens felt able to devote their attention to more immediate and important matters. The progress of the Reform Bill was being followed with intense interest. Lively meetings, rioting and burning the effigies of well-known protagonists, including one of the Archbishop, were fully reported in the local newspapers. Race week brought its own particular excitements. Visitors flocking to the city included some vagrants who travelled from Hull and Selby on 28 May in a ferry worked by a man called Thomas Hughes who lived in Beedham's Court off Skeldergate. The popular name for this filthy and overcrowded close was The Hagworm's Nest and it has the doubtful distinction of having been the starting point of many previous epidemics. 


\begin{tabular}{|c|c|c|c|c|c|c|c|c|c|c|c|c|c|c|c|c|c|}
\hline \multirow{2}{*}{$\begin{array}{l}\text { Number of } \\
\text { cases reported }\end{array}$} & \multicolumn{3}{|c|}{ June } & \multicolumn{4}{|c|}{ July } & \multicolumn{4}{|c|}{ August } & \multicolumn{4}{|c|}{ September } & \multicolumn{2}{|c|}{ October } \\
\hline & 2 & $\begin{array}{ll}9 & 16\end{array}$ & 2330 & 7 & 14 & 21 & 28 & 4 & 11 & 18 & 25 & 1 & 8 & 15 & 29 & 6.13 & 20 \\
\hline 140 & & & & & & & & & & & & & & & & & \\
\hline 130 & & & & & & & & & & & & & & & & & \\
\hline 120 & & & & & & & & & & & & & & & & & \\
\hline 110 & & & & & & & & & & & & & & & & & \\
\hline 100 & & & & & & & & & & & & & & & & & \\
\hline 90 & & & & & & & & & & & & & & & & & \\
\hline 80 & & & & & & & & & & & & & & & & & \\
\hline 70 & & & & & & & & & & & & & & & & & \\
\hline 60 & & & & & & & & & & & & & & & & & \\
\hline 50 & & & & & & & & & & & & & & & & & \\
\hline 40 & & & & & & & & & & & & & & & & & \\
\hline 30 & & & & & & & & & & & & & & & & & \\
\hline 20 & & & 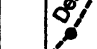 & & & & & & & & & & & & & & \\
\hline 10 & & & & & & & & & & & & & & & & & \\
\hline 0 & 8 & & & & & & & & & & & & & & & & \\
\hline
\end{tabular}

\begin{tabular}{ll}
\hline Total number of cases of cholera & 450 \\
\hline Total number of deaths & 185 \\
\hline Population of City at census & 25,357
\end{tabular}

Thomas Hughes became ill on 2 June. Mr. Wilson, the apothecary of the Dispensary, was sent for and decided that the man was suffering from cholera, so he called in a physician who agreed with the diagnosis. Both local newspapers had a paragraph on the start of the epidemic. The Gazette was factual: 'The disease has at last manifested itself in our city. The first alarm was on Sunday when a poor man named Hughes residing in The Hagworm's Nest became ill. He has now recovered and is doing well. The next was Greaves a sawyer living in the same court. He went home intoxicated on Monday night and was a corpse on Tuesday night. Barrett who kept The Anchor in Middle Water Lane became ill on Tuesday and died the next day. A girl of the town living in Water Lane was taken to the cholera hospital; a woman in Swan Street (in an advanced pregnancy of an illegitimate child) was the next victim. . . The editor of The Herald was more eloquent: 'Amidst the loud contentions of political strife, during the circulation of exaggerated rumours of riots, and whilst others were excited by glowing anticipations of future days of peace and prosperity, the Pestilence of India (like a thief in the night) silently and unobserved entered the city and took up its deadly stand on the vitals of the vitiated and in the 


\section{The 1832 Cholera Epidemic in York}

dwellings of the more virtuous poor ... we are however, prepared for it ... we feel confident that by the exertions of the Board of Health the evil will soon be subdued.' The peroration reached its climax with the admonition: "We trust that it will have produced the most desirable effects on the religious and moral deportment of all ranks.'

The Board of Health was summoned to receive the report of Hughes' illness. They realized that the situation was potentially serious and arranged to meet daily. They announced that on orders of the Privy Council all burials must take place within twelve hours of death. Bodies might not be taken into church; instead the clergyman should conduct the service in the graveyard. All burials must be at least one foot below the surface. It was quickly pointed out that this was quite impossible in many of the overcrowded churchyards so a subcommittee was appointed to consider alternative places for burial. The advisability of cleansing the city moats, ditches and streets was referred to medical opinion as some members feared that by disturbing their contents a 'foul and dangerous miasma would be released, and there was a risk of malaria'. The six-bedded cholera hospital was opened in a house adjoining St. George's churchyard.

Later in the day the majority of medical men in the city met at the Dispensary. Several went to see the patient as there were some who were still uncertain as to the true nature of the disease from which he was suffering. Some thought it was Cholera Morbus rather than genuine Indian Cholera; others thought it was essentially a fever. Some of the theories which they expressed on this, and other occasions during the summer have been preserved so it may be appropriate to consider them at this point.

There was difficulty in defining what was meant by cholera. They thought that if a patient survived the choleric stage, then a fever followed which resembled a consecutive fever or an ordinary contagious fever. Cholera could be due to a morbid state of the blood, to an interruption of the functions of certain organs, to an idiopathic affliction or to a morbid poison of unknown nature. These ideas are perhaps equally confusing today, partly because of the different meaning of words.

However they were very observant of the signs and symptoms of cholera which were divided into three stages. First stage: usually without warning a patient who had been in normal health had effortless and repeated diarrhoea which gradually assumed the appearance of rice-water. Profuse vomiting followed. Second stage: called the cold or choleric stage, could overlap the first stage. They described what was essentially a state of collapse resulting from the tremendous loss of fluid and electrolytes-the pulse became rapid and almost imperceptible, the skin was cold, pale and occasionally cyanotic. The eyes were sunken, the cheeks hollow, the tongue dry and little urine was passed. The voice became husky. The patient was restless and complained of severe thirst and cramps. At this stage death often occurred. The Third or Febrile stage: this developed if the patient survived. In milder cases the pulse became stronger and slower, the colour improved and the skin warm; it resembled a mild contagious fever they thought, with a gradual return to health. In the most severe cases there was no improvement but a rapid deterioration ending in death (presumably due to uraemia). Pneumonia was a complication in a few cases.

Later in the week, after medical men had given their approval, the Town Clerk was requested to arrange for the cleansing of roads, moats and ditches with quicklime 


\section{Margaret C. Barnet}

and the removal of their contents by night. Because of its reputation it was stressed that the Hagworm's Nest should receive special treatment. Soon people were complaining of the lime in the streets turning cobbles and puddles white and filling the air with a strong smell.

Streets in which cases of cholera occurred in 1832

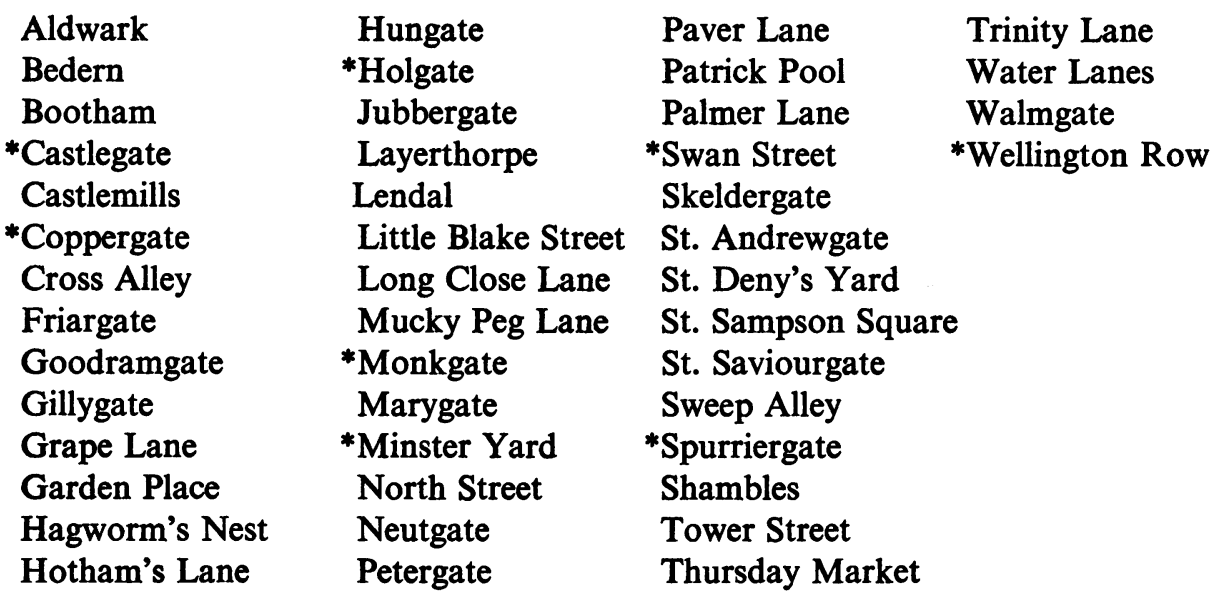

(With the exception of those marked with an asterisk, The Town Clerk reported to the Board of Health that none of these streets had drains, or if they existed they were defective.)

At first cases were confined to the Hagworm's Nest, Skeldergate, the Water Lanes across the river, the Shambles and Swan Street. The spread of the infection in the first few days can usually be followed. Thomas Hughes not only started it in his own family and in several others living in the Hagworm's Nest, but a few hours before becoming ill he had crossed the river to the Anchor Inn in Middle Water Lane infecting the publican, his family and maidservant. He also visited his uncle in the same lane. Next door was a common lodging-house where the keeper and most of the inmates became ill. Others in First and Third Water Lanes were believed to have got the infection from nursing or washing infected bedding. A party of travelling vagrants who had come into the city on 28 May from an infected place (possibly those brought by Thomas Hughes) lodged at a house in Swan Street where one of these men shared a bed with a young woman who died five days later. Her parents came from a village near Malton to her funeral, and took home not only her clothing but also the cholera. The first cases in the Shambles were a family who had lent a close-stool to the Barrett family at the Anchor Inn. It was returned in such a filthy state that after trying to clean it a neighbour took it away and threw it into the river.

By the end of the first week cholera had spread to many other areas. Parochial committees appointed visitors who called at every house on alternate days to inquire about the health of the inmates. Doctors reported new cases of cholera before 10.0 a.m. daily to the Board of Health and the patrol-captain inspected lodging houses regularly. The subcommittee recommended that a piece of land alongside the city walls, between the old Dog Kennels and Thief Lane (outside the site of the present railway station) 


\section{The 1832 Cholera Epidemic in York}

which was the property of the Corporation could be used for burials. The ground offered by the Dean 'in the kindest manner' was not so suitable. Four men were appointed to wrap corpses in pitch-cloth, and a covered cart and horse were engaged for funerals.

On 9 June The Herald announced joyfully: 'The Reform Bill Passed!!!' but The Gazette rather sourly suggested that in times of trouble citizens should not be contributing to a fund for celebratory dinners and illuminations. Instead the money should be given to the cholera hospital, thus relieving the burden on the poor-rates. Both papers united to give prominence to an unfortunate mistake by the sheriff. Abraham Peck was said to have died from cholera after refusing to take the medicines prescribed by the doctor. Without making inquiries or verifying the rumour the sheriff 'at his own expense' requested the overseer of the parish to take a coffin to the house. The rumour was undoubtedly exaggerated for the indignant Peck was able to write letters to the newspapers saying that he had followed medical advice and was now in perfect health.

This was the first of many letters about cholera. On 16 June a gentleman referred to prejudices prevailing amongst the lower classes who alleged that medical men were paid $£ 10$ per week by the parishes, and whilst they continued to be paid, then there would be cholera in York. The Board of Health felt it necessary to refute this rather muddled reasoning by pointing out that medical men treated poor patients free of charge. The only one to receive a salary was Mr. W. C. Anderson who had given up his private practice to devote all his time to the cholera hospital where he was living during the epidemic.

During the second week almost every house in the Water Lanes had a case of cholera. These streets were fumigated with burning pitch and all rooms were whitewashed. Financial matters began to trouble the Board. Each parish was ordered to levy a rate to pay for the expenses of the epidemic. Nineteen parishes agreed, ten refused and three did not reply to the Board's letters. At the meeting on 14 June the Rev. William Bulmer stated that his parish were determined not to make any contribution to expenses because a medical man had told him that there was no such thing as Indian Cholera in York. (Cries of: 'Name, Name!) Mr. Bulmer said he would not, but the gentleman was present in the room. Mr. Hope, apothecarysurgeon, rose to say that he was the person alluded to. He did not deny that there was a serious epidemic in the city, but he considered that it was not contagious. Dr. Wake replied forcibly, and after 'a long and desultory' conversation during which several people aired their eccentric views, all finally agreed that there was cholera in the city and that it was undoubtedly contagious. It was decided that if all parishes did not levy a rate then a compulsory order would be sought from the Privy Council. Doctors were already complaining that many patients could not afford to buy medicines which had been prescribed. They could be provided free by the Dispensary but only on the presentation of a subscriber's ticket and these were insufficient for the unprecedented demand. The Board decided to purchase $£ 10$ of these tickets for distribution to the sick poor.

In 1825 a new authority in the city had come into existence. These were the City Commissioners who were responsible for lighting, street-paving, street-cleaning and 


\section{Margaret C. Barnet}

drainage amongst other duties, and they were frequently in conflict with the Corporation. The Board of Health requested the commissioners to deal with various nuisances and to see that the streets were kept clean. Mr. Joseph Rowntree who was also a commissioner assured the Board that they had already done all they could to rid the city of all nuisances. He understood that no city in the North of England was so clean as York at present.

The new burial ground measuring 45 yards by 9 yards was licensed for burials on 12 June by the Archbishop. A vote of thanks was sent to him by the Board for 'graciously waiving his right to charge a fee for the service.' They also expressed their indebtedness to the Dean who had offered timber to fence in the ground. The first burial took place the following day. The body of Hannah Green of Middle Water Lane, who was described with unnecessary frankness in the press as: 'one of those unfortunate objects who infest our streets in a most depraved and immoral manner', was taken by horse and covered cart to the river, then by boat up the river for a short distance and finally carried by the four attendants to the new burial ground. Here the Rev. J. Salvin conducted a short service in the open air. 'It was feared that some prejudices by the lower orders might produce opposition to the interment. In the event, apart from a few boys watching from the city ramparts, only officials and police were present.'

There was certainly great resentment at the order forbidding bodies of cholera victims being taken into church. Angry relatives of Mrs. Fleming forced their way with her coffin into St. Michael, Spurriergate. The church wardens, threatened by physical violence, gave way and the young curate who was temporarily in charge agreed reluctantly to conduct the service. As a result the church was closed until it had been whitewashed and fumigated. Similar incidents occurred in other churches. Transport by river to the new burial ground was not always possible. The inhabitants of Micklegate and especially North Street along which the corteges travelled complained that they were being exposed to the risk of infection. On one occasion there was a disturbance resulting in a coffin being thrown in the river. On the other hand it was noticed that many women through idle curiosity and love of sensation brought small children to the burial ground to watch interments. Other complaints to the Board referred to constant visiting of sick persons and so spreading the infection. The four undertakers were advised to use only the widest and best-ventilated streets; not very easy as most were equally narrow.

Records of court proceedings provide some light relief in the report of an Irishwoman who had just made her exit from the house of correction to make an entrance into the justices' room. Voluble and passionate, she continued to curtsy to the magistrates whilst listening to the charge of being drunk and disorderly. She had asked to be sent home on discharge from prison: 'to me own dear country', so had been given clothing and money through the generosity of the governor. 'But how far will a shilling take me your honours?' She interrupted the embarrassed official. 'Sure; it was better to use it for rum which is well-known to prevent the cholera.' Rum cannot have been effective in all cases, for Nancy Modesty, addicted to ardent spirits and known to drink up to fourteen glasses a day, was an early victim of the disease.

Many correspondents were writing to the papers to give their own antidotes or 


\section{The 1832 Cholera Epidemic in York}

remedies for cholera. Purveyors of patent medicines had by this time got their publicity organized. In shops, in handbills and on the front pages of newspapers they extolled their products with testimonials from satisfied customers. Daffey's Elixir, Moxon's Effervescent Magnesium Aperient, and Morison the Hygienist's Genuine Vegetable Universal Mixture were guaranteed to cure every case of cholera as well as many other ailments. Morison's Pills were popular and there had been reference at a meeting of the Board to a mother who had given six of them to cure her child of a pain in the bowels. Later it was admitted to the cholera hospital where it died. Rumour had it, that it was the pills which had killed the child. 'A more unfounded report was never issued' wrote Mr. J. Webb of the British College of Health. These pills were not only innocent but all powerful. They were well known to cure every known bowel complaint ('by easy upward and downward evacuations') as well as fen-ague, gravel, abscesses, etc. The vivid testimony of Mrs. Ann Swaine of Walmgate could not fail to impress readers with its powers: 'The violent pains in my side could not be cured by The York Dispensary or by any medical man in this city, but fifteen Morison's Pills per night for three weeks caused me to quit such a quantity of bile and corruption from my stomach and bowels that I was a wonder to all who witnessed it. I have now discharged my maid, do all my own housework and can walk ten miles a day.' The editor, after interviewing several doctors, cautioned readers that professional opinion recommended sending for medical aid immediately. Whilst waiting the patient could safely take twenty drops of laudanum in a wineglass of brandy, but nothing else.

The doctors themselves admitted that the numerous and often contradictory methods of treatment which they employed indicated their lack of true understanding of the cause and action of cholera. Treatment usually followed traditional lines. In the First Stage the diarrhoea was treated with opium gr. $1 \frac{1}{2}$ about twice in 24 hours and calomel gr. 1 was added if the bowels continued to be purged, but no emetics were administered for the vomiting. 'Cautious' bleeding would relieve headache and muscle cramps. In the Second Stage it was felt necessary to control secretions by giving calomel every half-hour. Most doctors stressed total abstinence from all liquids, allowing only $\frac{1}{2}$ teaspoonful of water to help down the calomel. Coldness was relieved with mustard cataplasms to the stomach and limbs whilst an occasional mustard emetic 'comforted' the patient. Some gave ammonium carborate gr. 5. and the same quantity of magnesium carborate half-hourly. Galvanism was tried without success, as were rectal injections of 4-6 oz. of turpentine. If patients survived into the Third Stage, the mild cases only required a few leeches or a blister; moderate cases had small amounts of blood removed from the arm, more calomel and saline effervescing mixture two-hourly.

The severely ill were kept warm with mustard plasters, heated sandbags or bricks, warm baths if not too ill to be moved. Brandy, aromatic tinctures and camphor were administered, and of course more purgatives to clear out poisons and calomel to restore secretions. Catheterization was often necessary.

Some doctors felt it was cruel to ignore the intense craving for fluid, so they allowed small quantities of lemonade, tartaric acid in water, or an infusion of ginger in milk and sugar. 


\section{Margaret C. Barnet}

Other treatments which were tried in York included the Cold Water Treatment as recommended by Dr. Shute of Gloucester, but after two of Dr. Belcombe's patients died this was discontinued. Dr. Stevens' Saline Treatment method which had been published two years earlier in a paper to the Royal College of Physicians was also unsuccessful. Other doctors tried the suggestions of Dr. Lawrie of Glasgow who suggested cholera cases being given injections of laudanum or small quantities of whisky. Fatal results also followed injections of bullock's blood and even human serum. More interesting is the reference by Dr. Needham of Goodramgate to the use of intravenous saline injections. The solution consisted of two drachms of muriate of soda and two scruples of carbonate of soda in sixty ounces of water at a temperature of $108-110^{\circ} \mathrm{F}$. and was injected by means of a Read's common syringe. This was based on the methods adopted by Dr. Latta of Leith who recommended rapid replacement of lost body fluids. All that is known about its use in York is that of thirty cases treated in this manner only four recovered.

One doctor probably summed up the feelings of most of his colleagues at the end of the epidemic in York when he said that their treatment had been empirical, uncertain and frequently inefficacious.

On 23 June The Gazette announced that cholera was on the wane, all alarm subsided and that all places likely to be infected had been whitewashed. The victims were of two classes-poor or depraved. For the former a fund had been raised to help with food and clothing. There was no need for visitors to abstain from visiting the city as they were not likely to go to those parts where it occurred. Cholera was only infectious in certain cases-it was only if a person was predisposed that he would get cholera which was caused by lack of cleanliness, intemperance and low-living.

The Board of Health was by no means so optimistic. Cholera cases were multiplying in every ward of the city. The Dispensary was open for twelve hours a day treating patients and visiting them in their homes. Relieved of the necessity of paying for medical attention, the poorer people sought advice early. On one day in June the apothecary-surgeon saw 115 cases. Extra staff were appointed to help him and they ceased to ask for a ticket from a subscriber before issuing medicines. The drain on the finances of the institution was very great and it was not until 1835 that they received from the Board of Health's fund one hundred guineas as a liberal compensation for their work. The medical men could hardly cope with the extra work amongst their patients. In addition several were themselves suffering from diarrhoea and were probably sub-clinical cases of cholera although none was officially reported to have suffered from the disease. There were large numbers of cases of cholera in the County Hospital and the Asylum. The cholera hospital was quite inadequate to deal with the requests for admission. To release beds a wooden hut was erected for the convalescents on a site overlooking St. George's churchyard. Mr. Samuel Tuke was most concerned by the plight of destitute families who lacked food. He also appealed for old garments to clothe the convalescents. Many were unable to leave hospital or their own homes as their only clothes had been burned. Mr. George Hudson asked if clothing might not be disinfected by stoving so it was agreed to arrange for the loan of two stoves for this purpose. As early as 1805 the Central Board of Health 
had advised the Privy Council that in order to destroy what they described as specific poisons all infected clothing should be removed with a pair of tongs and thoroughly boiled and all other articles should be fumigated in sulphur for twenty-four hours. Leaving the provision of clothing to voluntary efforts, the Board authorized the purchase of a black suit and crepe scarf for the driver of the hearse, and a local draper presented black cloaks to the four undertakers.

Dr. Wake announced that the poor-house in Marygate was clean and well regulated but as there was a filthy crowded court next door where cholera had already broken out, the dividing wall was to be raised several feet to prevent infection spreading. Within a few hours of this statement two women had died from cholera in the institution. As the inmates slept two in a bed, the night rooms had no ventilation except through the day room, and any nursing, emptying of slops, etc. was carried out by old women and an idiot girl, it was not surprising that the number of cases increased alarmingly.

The vicar of St. George and St. Denys' churches complained that cholera victims were being buried in his already overcrowded churchyards. Officials of St. Maurice's church said that they could not cope with bodies from the County Hospital; parishes in which were situated the poor house and the Asylum had similar complaints. The Board said that they must do the best they could as the new burial ground could accept only a proportion of interments as it was not sufficiently large.

The financial report to the Board showed that the first three weeks of the epidemic had cost $£ 699$ including the cost of fitting out the hospital. Wages, medicines, food, and lime cost about $£ 82$ weekly. Mr. Anderson the house-surgeon was paid $£ 1010$ s. $0 d$. weekly, his assistant $£ 55 s .0 d$. and the nurses $£ 110 s$. $0 d$. An over-zealous member of the Board scrutinizing the accounts questioned the award of $£ 3$ extra to the wages of the clerk to the Board in recognition of all his additional work. A typical and often irrelevant discussion followed, the clerk took offence and resigned. Fearing that he could not be replaced, the Board hastily implemented the agreement and as a bonus offered a vote of thanks for all his efforts.

By the end of the month there had been a total of at least 175 cases with 64 deaths. But worse was to come. During the first week in July there were 128 cases with 40 deaths. This was the peak of the epidemic and was followed by an equally dramatic fall. On 21 July the editor of The Gazette could again, and with more reason, predict that 'the Scourge is nearly defeated ... and Old Ebor is almost itself again.'

The Board still had many problems. The accumulation of piles of night soil awaiting collection on the pavements had to be covered with lime. They received angry complaints about the unpleasantness resulting from the burning in the streets of infected clothing, bedding and furniture removed from houses in the comparatively select area of Minster Yard as well as in the Water Lanes. The Yorkshire Insurance Company was asked to lend its leather fire-hoses which could be used to wash the streets. It was estimated that three men working for twelve hours daily could do the work satisfactorily. The Board was surprised and disconcerted to learn from the Town Clerk that there was a complete lack of drains in many of the streets where the infection rate was highest. 


\section{Margaret C. Barnet}

In order to reduce costs it was decided to reduce staff at the hospital, also the whitewashers, undertakers' assistants and the home-nurses, and all remaining were put on half pay. The press felt that the best means of saving money would be by dispensing with the Board of Health. The latter were meanwhile considering suitable remuneration of all the medical men in the city. After much discussion and a gradual scalingdown of the proposed awards it was finally agreed that it would be sufficient to recall the medical profession's zeal and activity exposing themselves and their families to danger whilst working to stop the plague. In a tautological outburst they were accorded grateful thanks, cordial and heartfelt gratitude. There was great distress amongst the poor. Voluntary funds provided tickets for 4-5,000 free meals daily. Mr. Rowntree recommended levying a penny rate but this was defeated as the Corporation considered that it could not provide medicines or food from the rates.

The arguments about the burial ground were now absorbing the attention not only of the Board but also of many citizens. George Hudson was very active on this issue and ensured that it received the maximum publicity. He was at the beginning of his meteoric career and had decided that support of the Tory cause could offer the best opportunities as he entered public life. The members of the Board of Health were mainly Tories whilst the City Council was largely Whig. The row enabled him to champion the distressed relatives of the deceased. He stressed the need to have the new burial ground consecrated. It was ridiculous he complained for the Corporation to say now that the land could only be granted for twenty years; it was waste land which had never been used for any purpose. It should be set aside in perpetuity or at least for 999 years for the peace of mind of relatives. It would be most distressing if there was any possibility of the ground being used for any other purpose in the future. Mr. Jonathan Gray questioned the reason for the Corporation's decision which was an outrage and placed its character at stake. The Archbishop intervened to point out that he was unable to consecrate ground which was only leased for a short period. Mr. Rowntree added to the confusion by expressing the opinion that as the burial ground was part of the city ramparts it belonged to the Crown and therefore York Corporation had no rights over it. Another gentleman suggested that the land belonged to the freemen of York who had not been consulted. The editors of the newspapers expressed righteous indignation as they condemned the Corporation for its laboured effort to extricate itself from a very awkward position, and the next meeting of the City Council was a lively one. They offered to extend the lease of the ground for a longer period-fifty or ninety-nine years, but these suggestions were not well received by anyone. Deputations of relatives pleaded for the argument to be settled so that the ground could be consecrated and the dead might rest in peace. The Lord Mayor assured the city that if the land was consecrated now, then the Corporation would never dream of interfering with it. The Archbishop however was adamant. He would not consecrate leased land. Finally after weeks of wrangling the Corporation gave way, granting the land in perpetuity to trustees and giving a solemn promise that it was never to be used for any other purpose and the bodies were never to be exhumed. After this agreement the burial ground was then consecrated with due solemnity.

At the beginning of September the Board, after having been perhaps unnecessarily 


\section{The 1832 Cholera Epidemic in York}

frank in the past, now ordered the exclusion of the press from its meetings as they felt that the citizens might be alarmed by accounts of the progress of the epidemic. It would be more correct to say that several members were annoyed at what they considered to be incorrect reports and magnification of disagreements. Once again the editors took the opportunity to compose vitriolic articles, this time on the themes of democracy, the freedom of the press and sinister decisions being taken behind closed doors. By these means and by such brief comments as: 'we are informed' or 'the Board has only admitted to 24 cases with 12 deaths this week' they were able to suggest that the cholera was worse than it seemed.

The epidemic was however dying down, and there was a steady decline until on 15 October The Herald said that Old Ebor was completely restored to health, whilst his colleague agreed that the epidemic was now over except for a case of a small child 'which is of no consequence'. The Board of Health was disbanded. Its last effort was to recommend plans for a seven-foot-high stone wall to enclose the graveyard which was to be planted with trees. Fortunately more aesthetic views prevailed, or perhaps funds were insufficient, for only iron railings were erected, and these have now disappeared leaving only a stretch of grass, gravestones, a few shrubs and trees, one of which is sometimes rather inappropriately decorated with coloured lights at Christmastime.

The epidemic had caused at least 450 cases with 185 deaths amongst a population of 25,357 . The newspapers and some of the clergy could say that the visitation of the cholera had not been without its good effects as it had given a firmer tone to the consistant Christian, so it had caused others to think on sacred things'; but little of immediate practical value appears to have resulted, apart from the opening of a new cemetery in 1836. Only 6,000 yards of inadequate and ineffective drains were laid during the next ten years; 'the need for economy slows down the work'. There was talk in the Council of pulling down the city walls to improve the ventilation of the narrow streets and so dispelling the evil miasmas, but fortunately nothing came of it. There was a suggestion of demolishing the insanitary Water Lanes and building a market on the site, but together with the Hagworm's Nest they survived for many more years.

In 1844 there was published The Report on the State of York, In Reply to Questions Circulated by the Commissioners for Inquiring into the State of large Towns. This was largely the work of Dr. Thomas Laycock of York who was secretary to the local committee carrying out the inquiry. It was a remarkable work, a methodical survey of many aspects of the life and health of the inhabitants; water supplies, drainage and disposal of night soil; sickness, child mortality, death-rates and the availability of medical care; wages, rents and costs of living. All these facts, and many others, were emphasized by the use of statistical tables. As Dr. Laycock considered that conditions were the same as in $\mathbf{1 8 3 2}$ then the picture which his report presented may be a fairly accurate representation of the state of York at the time of the cholera epidemic.

Drainage in York was difficult because the River Foss was dammed up at the Castle Mills to aid navigation and this interfered with the drainage of the eastern half of the city, whilst many low-lying districts were subject to flooding by the River 


\section{Margaret C. Barnet}

Ouse. The medieval King's Ditches or drains at the back of certain streets were filled with stagnant water. Some streets still had open central drains and these were often above the level of courts and yards. Domestic water was obtained from shallow wells or from the rivers, except for a few who could afford a supply from the Waterworks. Houses of wealthier people had water-closets which emptied into drains or cess-pools. In the newly erected (1823 and 1830) tenements one privy was provided for every 4-14 families, its position being selected without regard to the health or comfort of the inhabitants. On the Long Close Lane there was one at each end of the street. In the Water Lane many old houses were without any privy, so the inhabitants went by stealth into their neighbours' or used the street. The contents of pigstyes and night soil were removed by barrow into the streets to await collection and transport to the dung-hills in various parts of the city. Manure merchants sold it to farmers at a yearly profit of $£ 10,000$. Incidentally the largest open cess-pool in the city was situated in the courtyard of the County Hospital. Overcrowding in old property was appalling. Of 98 families living in The Bedern, 67 had only a single low, damp room.

Every street and most houses were inspected for the survey by a team of twelve district-visitors who included five medical men. Two unsavoury examples from their reports are typical:

Far Water Lane-Nos. 18-21 are subject to flooding. All the houses are crowded together in the narrow street. Rooms are generally $12 \times 12$ feet and only 7-8 feet high, and all are damp. Several families have only one room. For the want of a convenient supply of water cleanliness ... is discouraged. Most people fetch it from the river. . . . many houses are not connected to drains. The common privies are dirty, offensive and close to dwellings. Hope Street-There are pigstyes in almost every yard. No. 7 is crowded and unhealthy, No. 37 is filthy, there is an abominable smell from the many cats there; the occupant seems rather eccentric. No. 58 complains of his neighbours emptying their chamberpots into his yard. The two privies for every eight houses are full and running over.

Further condemnation of the insanitary state of York came a few years later from no less a person than Dr. John Snow. He was born in York and, had received his early education in the city. In his Mode of Communication of Cholera, published in 1855 he described an outbreak of cholera in York in July 1849:

... it was first chiefly prevalent in some narrow streets near the river called the Water Lanes. The inhabitants had been in the habit from time immemorial, of fetching their water from the river at a place near which one of the chief sewers of the town empties itself; and recently a public necessary had been built, the contents of which were washed every morning into the river just above the spot at which they got the water. In a short time 20-30 deaths occurred in this locality; but medical men considering the impure water injurious, the people were supplied from the Waterworks with water obtained from the river at a point some distance above the town and the cholera soon ceased nearly altogether at this point in the city, but continued to spread in some other parts. The cholera having thus abated in the Water Lanes, the gratuitous supply of clean water was cut off and the people went to the river as before ... and ... it soon broke out again in this locality, and in the first few days of September 8 deaths occurred among the persons who used water obtained direct from the river. The tap was again opened and the river water interdicted, and the cholera spread ceased and did not recur.

Dr. Laycock was undoubtedly correct when he said that he had no hesitation in declaring that the cholera epidemic in York was fatal to the people in proportion to the deficient drainage in their locality. 
The 1832 Cholera Epidemic in York

\section{REFERENCES}

York Herald, Newspaper Files, York Reference Library.

York Gazette, Newspaper Files, York Reference Library.

Records, Minute Books, Papers etc., York Medical Society.

Needham, James Peacock, Facts and Observations Relative to The Disease Commonly Called Cholera, as it has Recently Prevailed in the City of York, London, Longman, 1833. York Medical Society.

Snow, Jown, On the Mode and Communication of Cholera, London, J. Churchill, 1855. York Medical Society.

Allen, Oswald, History of York Dispensary, York, Pickering, 1845. York Medical Society. Royal Commission on the State of Large Towns, London, W. Clowes, 1845. York Medical Society.

Victoria County History. York Reference Library. 